\title{
PEMETAAN MINAT KARIR SISWA PAKET C
}

\author{
Monika \\ Fakultas Psikologi, Universitas Tarumanagara Jakarta \\ Email: monika@fpsi.untar.ac.id
}

\begin{abstract}
ABSTRAK
Program Paket $C$ adalah program pendidikan nonformal sebagai alternatif dari Dinas Pendidikan yang diperuntukkan bagi siswa-siswi yang putus sekolah atau yang tidak sempat menempuh pendidikan formal SMA karena berbagai alasan. Setelah lulus dari program paket $C$, para siswa dihadapkan pada pilihan karir yang akan mereka tekuni di dunia kerja. Tujuan dari pelaksanaan abdimas ini adalah untuk melakukan pemetaan minat karir siswa paket $C$, untuk diketahui peta minat karir siswa paket $C$ secara umum, agar diketahui tujuan pembelajaran di program paket $C$ dapat diarahkan sesuai peta minat karir siswa. Selain itu, pemetaan minat karir ini dapat menjadi acuan agar selanjutnya dapat dilakukan pendampingan secara lebih intensif bagi siswa paket $C$ dalam merencanakan karir mereka. Teknik pemetaan karir yang digunakan dalam pelaksanaan abdimas ini adalah dengan menggunakan tes minat Holland. Teori Holland mengenai tipe kepribadian yang sesuai dengan interaksi seseorang dengan lingkungan pekerjaannya. Partisipan dalam pelaksanaan abdimas ini adalah 62 siswa paket C. Namun demikian, hasil tes minat yang dapat dipetakan diperoleh dari 37 siswa. Hasil dari pemetaan karir ini tampak bahwa sebesar 43,2\% siswa memiliki tipe kepribadian Social, sebesar 16,2\% memiliki tipe kepribadian Realistic dan Artistic, sebesar 13,6\% memiliki tipe kepribadian Conventional, dan sebesar 5,4\% memiliki tipe kepribadian Investigative dan Enterprising. Selanjutnya luaran dari kegiatan abdimas ini berupa modul perencanaan karir bagi siswa Paket $C$ berdasarkan peta minat karir siswa.
\end{abstract}

Kata kunci: Minat Karir, Paket C, Tipe Kepribadian, Pemetaan, Modul Perencanaan Karir

\section{PENDAHULUAN}

Program Paket $\mathrm{C}$ adalah program pendidikan nonformal sebagai alternatif dari Dinas Pendidikan yang diperuntukkan bagi siswa-siswi yang putus sekolah atau yang tidak sempat mengecap pendidikan formal SMA karena berbagai alasan. Oleh karena beragamnya alasan inilah yang juga menyebabkan pilihan dan keputusan karir pada siswa Paket $\mathrm{C}$ juga sangat beragam. Situasi yang dialami oleh siswa Paket $\mathrm{C}$ ini wajar dialami oleh remaja atau siswa yang menempuh bangku SMA atau sederajat. Mereka dihadapkan pada masalah karir atau masalah pemilihan bidang pekerjaan yang akan digeluti selanjutnya.

Herr (dalam Niles\&Bowlsbey, 2009) mengungkapkan bahwa karir adalah totalitas serangkaian peran yang individu mainkan sepanjang rentang kehidupan mereka. Definisi ini lebih luas dari definisi yang dikemukakan oleh Sears yang mendefinisikan karir sebagai totalitas pekerjaan yang dilakukan seseorang sepanjang hidupnya. Selanjutnya, Super (dalam Niles\&Bowlsbey, 2009) juga menjelaskan bahwa proses perkembangan karir adalah proses sepanjang rentang kehidupan dan konsep diri seseorang memainkan peran yang sangat besar dalam perkembangan karir seseorang.

Kesulitan dalam mengambil keputusan karir dapat disebabkan oleh berbagai hal, diantaranya kurangnya informasi, adanya informasi yang tidak konsisten, dan ketiadaan tempat untuk konsultasi atau berdiskusi masalah karir ini. Kekeliruan dalam memilih bidang studi atau bidang pekerjaan dapat terjadi karena kurang informasi mengenai minat-bakat yang dimiliki oleh para siswa. Menurut Gati, Krausz, dan Osipow (1996) membuat suatu keputusan karir merupakan hal yang kompleks. Proses pengambilan keputusan karir memiliki karakteristik yang sama seperti pada proses pengambilan keputusan lainnya, yang berarti bahwa proses yang ada melibatkan seorang individu yang memilih apa yang dia rasa paling tepat dari berbagai kemungkinan karir berdasarkan pada perbandingan dan evaluasi atas alternatif-alternatif karir, dengan 
memperhatikan kenyataan bahwa perbandingan dan proses evaluasi tersebut dipengaruhi baik oleh karakteristik program pendidikan/profesi dan karakter individual.

Teori John Holland (dalam Niles\&Bowlsbey, 2009) mengenai tipe dan interaksi orang dengan lingkungannya, menyampaikan perspektif yang menggambarkan perbedaan individual dalam tipe kepribadian. Holland teori digambarkan sangat terstruktur dan interaktif, karena teori tersebut mencoba mengkaitkan antara beragam karakteristik kepribadian dengan pekerjaan atau profesi tertentu. Teori ini memiliki empat asumsi dasar yaitu: 1) sebagian besar orang dikelompokkan dalam 6 tipe: realistic, investigative, artistic, social, enterprising, conventional, 2) terdapat enam tipe lingkungan kerja: realistic, investigative, artistic, social, enterprising, conventional, 3) orang mencari lingkungan kerja yang dapat melatih ketrampilan dan kemampuan mereka, mengekspresikan sikap dan nilai, serta sejalan dengan peran mereka, 4) perilaku seseorang tampak dari interaksi antara kepribadian dan karakteristik lingkungan.

Mempertimbangkan kondisi siswa Paket $\mathrm{C}$ yang sedang mempersiapkan karir mereka, maka dipandang penting untuk melakukan pemetaan minat karir siswa paket $\mathrm{C}$, serta memberikan pendampingan dalam perencanaan karir. Pemetaan minat karir ini dapat dilakukan melalui tes minat Holland untuk menggali arah minat siswa yang nantinya disesuaikan dengan kemampuan (bakat) setiap siswa. Hasil tes diharapkan dapat memberikan masukan bagi siswa untuk menentukan jurusan bidang studi atau bidang pekerjaan yang lebih sesuai dengan diri mereka, sehingga para siswa dapat merencanakan karir yang benar-benar sesuai dengan minat, bakat, dan tipe kepribadian yang mereka miliki.

\section{METODE PELAKSANAAN PKM \\ Khalayak Sasaran}

Sasaran kegiatan ini adalah siswa kejar paket C sebanyak 70 siswa. Namun demikian, pada kenyataannya jumlah siswa yang hadir adalah sebanyak 62 siswa dan hasil tes minat Holland yang berhasil dipetakan adalah sebanyak 37 siswa.

\section{Pelaksanaan}

Guna mengatasi permasalahan-permasalahan yang telah dikemukakan sebelumnya, maka pelaksana abdimas menawarkan solusi berupa program-program yang konkrit dan tepat guna bagi para siswa dan pengajar Paket $\mathrm{C}$, serta bagi pengelola Pusat Kegiatan Belajar Masyarakat (PKBM). Adapun program-program tersebut antara lain, sebagai berikut: (1) pembicaraan dengan Penanggung jawab dan pengajar di PKBM, dengan tujuan membicarakan permasalahanpermasalahan yang dihadapi siswa dan pengajar Paket $\mathrm{C}$ dan diskusi mengenai upaya penanganannya, (2) seminar mengenai karir dan pengambilan keputusan karir, serta pemberian tes minat Holland kepada para siswa Paket $\mathrm{C}$, dengan tujuan memberikan pemahaman tentang bakat minat yang dimiliki dan pemilihan karir, (3) pemetaan minat karir agar diketahui arah karir para siswa paket $\mathrm{C}$, sehingga pengajar dan pengelola PKBM dapat memiliki arah yang jelas dalam mendidik dan mengajar siswa paket $\mathrm{C}$, serta mampu memberikan pengajaran yang efektif dan tepat guna bagi masa depan para siswa, dan (4) penyusunan modul perencanaan karir bagi siswa Paket $\mathrm{C}$, dengan tujuan membantu para siswa Kejar Paket $\mathrm{C}$ mengatasi permasalahanpermasalahan mereka, terutama terkait permasalahan dalam pemilihan dan perencanaan karir.

Kegiatan dilaksanakan pada bulan Februari - Juli 2018, bertempat di Pusat Kegiatan Belajar Masyarakat di daerah Kebon Jeruk, Jakarta Barat 


\section{HASIL DAN PEMBAHASAN}

\section{Pembicaraan dengan penanggung jawab PKBM}

Pelaksana kegiatan pengabdian kepada masyarakat (abdimas) bertemu dengan Kepala PKBM X untuk membicarakan permasalahan di PKBM X, khususnya terkait masalah yang dihadapi siswa kejar paket. Kepala PKBM X menyampaikan bahwa permasalahan yang dihadapi siswa kejar paket sangat kompleks. Motif atau latar belakang para siswa tersebut mengikuti program kejar paket juga beragam, ada yang dikarenakan untuk memperoleh ijazah karena selama ini mengikuti program homeschooling, ada yang karena dikeluarkan dari sekolah umum karena permasalahan-permasalahan tertentu, ada siswa yang usianya sudah dewasa atau bahkan lansia, dengan tujuan untuk memperoleh ijazah setara SMA.

Kepala PKBM melihat para siswa kejar paket ini masih kurang memahami etos kerja dikarenakan sikap yang kurang serius saat kegiatan belajar mengajar. Muara dari permasalahan ini diduga karena mereka belum memiliki arah karir yang jelas, sehingga mereka terkesan belum memberikan perhatian yang khusus terhadap pelajaran-pelajaran yang dipelajari di sana. Selain itu, berbeda dengan sekolah SMA pada umumnya yang memiliki guru Bimbingan dan Konseling di sekolah, program kejar paket $\mathrm{C}$ tidak memiliki guru khusus yang dapat dijadikan siswa sebagai tempat bertanya atau konseling untuk permasalahan karir mereka.

Berangkat dari permasalahan tersebut, maka berdasarkan diskusi yang telah dilakukan oleh pelaksana abdimas dengan Kepala PKBM, maka diputuskan untk mengadakan pendampingan karir bagi siswa kejar paket C. Kegiatan ini dimulai dengan pemberian Tes Minat SDS Holland, kemudian dilanjutkan dengan seminar "Perencanaan Karir Siswa Kejar Paket C", dan diakhiri dengan pembuatan modul pendampingan siswa yang membutuhkan pendampingan secara khusus dalam perencanaan karir mereka.

\section{Seminar dan pemberian Tes Minat Holland}

Seminar ini dihadiri oleh 62 peserta dari siswa paket C. Seminar diberikan oleh Monika, M.Psi. Pada sesi ini dijelaskan mengenai pengertian bakat, cara mengidentifikasi bakat, faktor-faktor yang mempengaruhi perkembangan bakat, serta hubungan bakat dengan minat seseorang. Selanjutnya diberikan tes minat Holland yang dalam pelaksanaannya administrasi tes minat dibantu oleh Peiter Houtama yang merupakan mahasiswa Fakultas Psikologi Untar angkatan 2014. Selain membantu dalam proses administrasi, Peiter juga membantu memberikan penjelasan kepada para siswa paket $\mathrm{C}$ yang kesulitan dalam memahami dan menjawab pertanyaan-pertanyaan dalam Tes Minat Holland.

Pada sesi berikutnya, pelaksana abdimas menjelaskan mengenai hasil Tes Minat Holland yang telah dilakukan sebelumnya. Pelaksana abdimas menjelaskan tentang 6 tipe minat yang ada di dalam Tes Minat Holland, yaitu Realistic, Investigative, Artistic, Social, Enterprising, dan Conventional (dalam Niles\&Bowlsbey, 2009). Meski sering digunakan oleh para psikolog dalam mengidentifikasi minat seseorang, Tes Minat Holland ini juga sudah diketahui secara umum dan dapat dipergunakan secara praktis untuk mengidentifikasi minat seseorang

Selanjutnya diberikan tes minat Holland yang dalam pelaksanaannya, administrasi tes minat dibantu oleh Peiter Houtama yang merupakan mahasiswa Fakultas Psikologi Untar angkatan 2014. Selain membantu dalam proses administrasi, Peiter juga membantu memberikan penjelasan kepada para siswa paket $\mathrm{C}$ yang kesulitan dalam memahami dan menjawab pertanyaan-pertanyaan dalam Tes Minat Holland. 


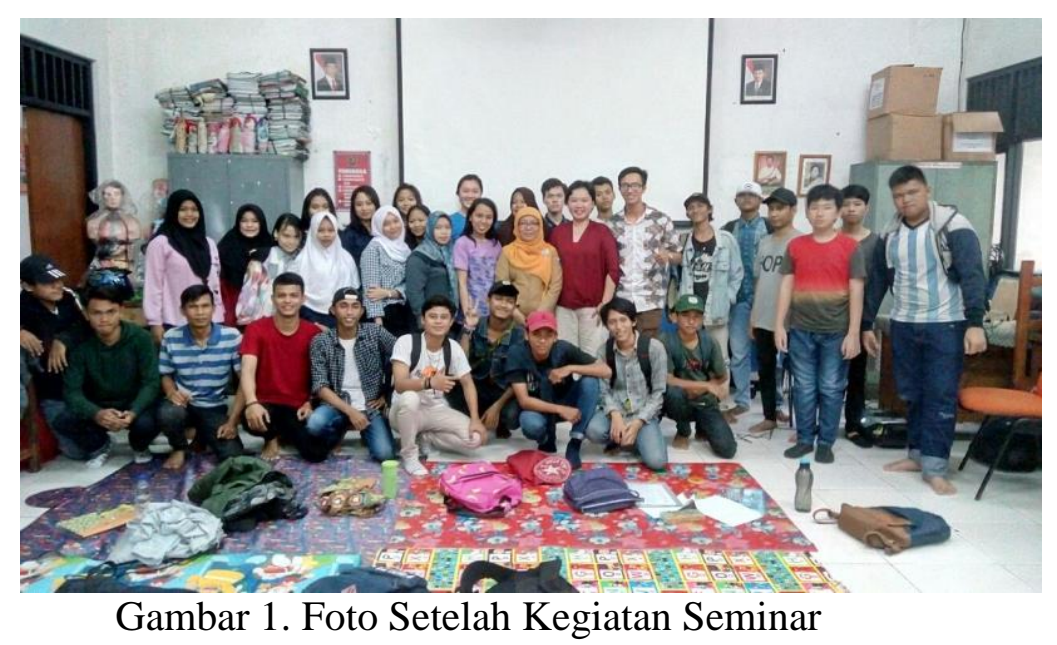

\section{Pemetaan Minat Karir}

Jumlah siswa yang hadir pada acara seminar ini adalah sebanyak 62 siswa dan hasil tes minat Holland yang berhasil dipetakan adalah sebanyak 37 siswa. Banyaknya data yang tidak valid terlebih dikarenakan banyak siswa yang datang terlambat saat pelaksanaan tes minat Holland. Selain itu, juga banyak data yang tidak lengkap karena ada bagian yang tidak diisi oleh siswa.

Dari 37 hasil tes minat yang diperoleh, didapatkan data sebagai berikut: sebesar $43,2 \%$ siswa memiliki tipe kepribadian Social, sebesar 16,2\% memiliki tipe kepribadian Realistic dan Artistic, sebesar 13,6\% memiliki tipe kepribadian Conventional, dan sebesar 5,4\% memiliki tipe kepribadian Investigative dan Enterprising. Untuk lebih jelasnya dapat dilihat pada tabel berikut:

Tabel 1 Peta Minat Karir Siswa Paket C

\begin{tabular}{lll}
\hline Tipe Kepribadian & Frekuensi & Persentase \\
\hline Realistic & 6 & 16.2 \\
Investigative & 2 & 5.4 \\
Artistic & 6 & 16.2 \\
Social & 16 & 43.2 \\
Enterprising & 2 & 5.4 \\
Conventional & 5 & 13.6 \\
\hline Total & 37 & 100 \\
\hline
\end{tabular}

Hasil dari pemetaan karir menunjukkan bahwa sebagian besar siswa paket $\mathrm{C}$ memiliki tipe kepribadian Social yaitu sebesar $43.2 \%$, yang artinya orang dengan tipe kepribadian ini menyukai karir yang bersifat sosial, seperti guru, terapis bicara, pekerja keagamaan, konselor, perawat, dll. Selain itu, mereka juga suka untuk berada dengan orang lain dan membantu orang lain mengatasi masalahnya. Selanjutnya masing-masing sebesar $16.2 \%$, menunjukkan bahwa para siswa cenderung memiliki tipe kepribadian Realistic dan Artistic. Realistic artinya orang dengan tipe kepribadian ini menyukai karir yang realistis seperti mekanik mobil, surveyor,ahli listrik. Mereka menyukai pekerjaan di luar ruangan dengan menggunakan alat-alat dan mesin. Sedangkan Artistic artinya orang dengan tipe kepribadian ini menyukai pekerjaan seni, seperti komposer, musisi, penari, aktor, penulis,dll. Mereka suka bekerja dengan menggunakan ide-ide kreatif dan ekspresi diri daripada pekerjaan yang menuntut rutinitas dan peraturan.

Pada urutan selanjutnya, sebanyak $13,6 \%$ siswa paket $\mathrm{C}$ menunjukkan tipe kepribadian Conventional, yang artinya orang dengan tipe ini menyukai pekerjaan yang bersifat konvensional, seperti analis keuangan, akuntan, bankir, ahli pajak, sekretaris, dll. Mereka suka untuk bekerja dalam ruangan dan mengatur sesuatu. Pada dua urutan terakhir, masing-masing 
sebesar 5,4\%, menunjukkan minat siswa adalah pada Investigative dan Enterprising. Investigative artinya orang dengan tipe ini menyukai karir yang bersifat penelitian seperti ahli biologi, ahli kimia, ahli fisika, ahli geologi, ahli antropologi, laboran, teknisi medis, dll. Mereka cenderung suka untuk mengeksplorasi dan mengerti sesuatu atau kejadian-kejadian. Sedangkan Enterprising artinya orang yang menyukai tugas-tugas dimana mereka dapat bertindak sebagai pemimpin (leader), mereka me nikmati untuk membujuk atau meyakinkan orang untuk melihat dari sudut pandang mereka (dalam Niles\&Bowlsbey, 2009).

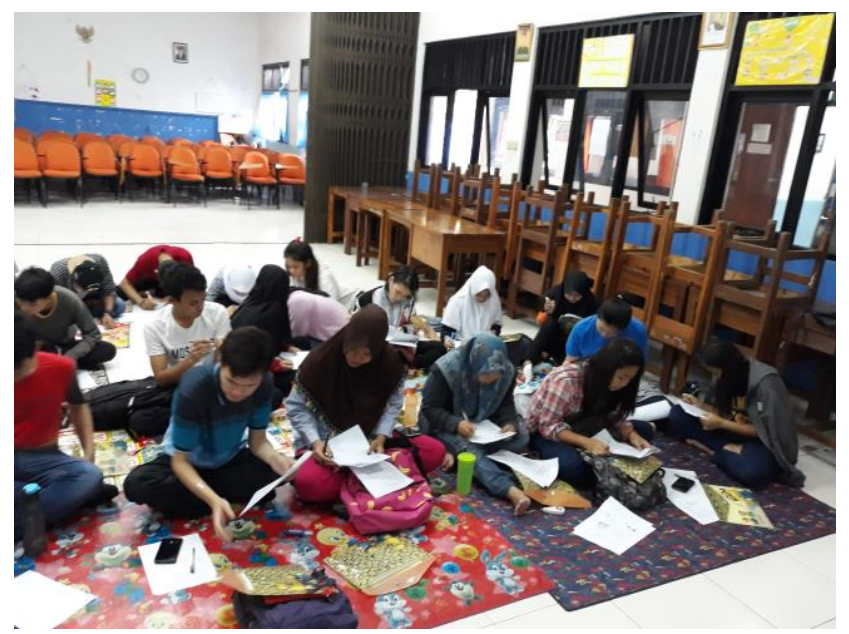

Gambar 2. Foto Kegiatan saat Siswa Paket C mengerjakan Tes Minat

\section{Penyusunan Modul Perencanaan Karir}

Sebagai tindak lanjut dari seminar Perencanaan Karir bagi Siswa Kejar Paket C, maka pelaksana abdimas menyusun Modul Perencanaan Karir bagi siswa kejar paket. Modul ini sebelumnya pernah diberikan kepada mahasiswa Fakultas Psikologi yang mengambil Mata Kuliah Bimbingan Karir. Langkah-langkah yang dilakukan pada modul ini adalah dengan menyederhanakan bahasa dan memperjelas langkah-langkah konkrit yang harus dilakukan siswa dalam merencanakan karir mereka. Selanjutnya modul ini akan diujicobakan pada beberapa siswa Paket $\mathrm{C}$ yang berminat mengikuti sesi pendampingan karir, serta dapat dipakai secara umum bagi siswa yang ingin merencanakan karir mereka.

\section{KESIMPULAN DAN SARAN \\ Kesimpulan}

Berdasarkan hasil pemetaan karir yang dilakukan tampak bahwa tiga bidang minat karir tertinggi siswa paket C adalah pada Tipe Social, Realistic, dan Artistic. Dengan demikian dapat disimpulkan bahwa sebagian besar siswa paket $\mathrm{C}$ menyukai pekerjaan yang bersifat sosial seperti membantu orang lain, menyukai pekerjaan di luar ruangan dengan menggunakan alat-alat dan mesin, dan juga suka bekerja dengan menggunakan ide-ide kreatif dan ekspresi diri.

Selanjutnya pelaksana abdimas menyusun Modul Perencanaan Karir bagi siswa kejar paket, yang berisi langkah-langkah praktis dalam merencanakan karir mereka. Dengan adanya modul ini diharapkan para siswa kejar paket $\mathrm{C}$ dapat merencanakan karir mereka melalui tahapantahapan yang diberikan. Langkah-langkah ini dapat membantu siswa mempersiapkan karir mereka dengan lebih baik. 


\section{Saran}

Dari peta minat karir ini, selanjutnya para tutor dan pendidik paket $\mathrm{C}$ dapat mengarahkan para siswa paket $\mathrm{C}$ untuk dapat lebih memahami dirinya (salah satunya dengan memahami minat karir mereka), serta mengoptimalkan minat dan bakat mereka. Kegiatan yang dilakukan di program paket $\mathrm{C}$ dapat diarahkan ke kegiatan yang sifatnya sosial, teknis, praktis, dan juga kreatif, misalnya dengan menghasilkan suatu karya seni tertentu, yang dibuat dengan menggunakan mesin/peralatan teknik, dan kemudian hasilnya dapat digunakan untuk orang-orang yang membutuhkan. Dengan adanya kegiatan-kegiatan ini, diharapkan para siswa dapat lebih bersemangat menjalani pendidikan mereka di program paket $\mathrm{C}$, karena mereka dapat mengeksplorasi minat dan bakat mereka melalui kegiatan yang diadakan, dan mereka dapat menemukan makna dari hasil pekerjaaan mereka yang bermanfaat bagi lebih banyak orang.

Selain itu modul perencanaan karir juga dapat diberikan pada siswa Paket $\mathrm{C}$ yang ingin merencanakan karir mereka. Para siswa diharapkan dapat mengikuti langkah-langkah yang ada pada modul tersebut, sehingga mereka dapat memahami diri mereka dengan lebih baik, dapat mempertimbangkan alternatif karir yang dapat diambil, dapat mengambil keputusan karir yang tepat, serta pada akhirnya dapat merencanakan langkah-langah konkrit ke depan untuk mempersiapkan karir mereka.

\section{Ucapan Terima Kasih (Acknowledgement)}

Terima kasih kepada Direktorat Penelitian dan Pengabdian kepada Masyarakat yang telah mendanai pelaksanaan kegiatan Pengabdian Kepada Masyarakat (PKM) ini. Selain itu, secara khusus pelaksana PKM juga mengucapkan terima kasih yang sebesar-besarnya kepada Ibu Meike Kurniawati, S.Psi., M.M. yang telah membantu proses pelaksanaan kegiatan PKM ini, sehingga kegiatan PKM dapat berjalan dengan lancar.

\section{REFERENSI}

Capuzzi, D. \& Stauffer, M.D. (2006). Career counseling: foundations, perspectives, and applications. Boston: Pearson Education

Dacey, J.S \& Lennon, K.M. (1999). Understanding creativity. San Fransisco: Josey - Bass

Dariyo, A. (2014). The Role of Parent Support On Creativity Improvement of The Creative People. Procedding (tidak diterbitkan): Seminar Nasional: Ketahanan Keluarga Sebagai Aset Bangsa. Malang: Universitas Merdeka Malang

Flannery, M.E., (2010). Top eight challenges teachers face this school year. Diunduh tanggal 20 Oktober 2015 dari http//www: neatoday.org/2010/09/13

Gysbers, N.C., Heppner, M.J., Johnston, J,A. (2009). Career counseling: context, processes, and techniques. Alexandria, VA: American Counseling Association.

Isaacson L.E.\& Brown, D. (1993). Career information, career counseling, career development. Needham Heights, Massachusetts: Allyn and Bacon.

Kusmayadi, I. (2011). Membongkar kecerdasan anak: Mendeteksi bakat dan potensi anak sejak dini. Jakarta: Gudang Ilmu

Munandar, S.U. (1997). Strategi pengembangan keberbakatan \& kreativitas. Jakarta: Grassindo.

Negara,C.S., Prihantono, F.X.S., \& Sinambela. F.S. (2000). Analisa Faktor-faktor Pembentuk Kreativitas pada Tim Kreatif Biro Iklan di Surabaya. Anima, 15 (3), 280 - 292.

Niles, S.G. \& Bowlsbey, J.H. (2009). Career development interventions in the $21^{\text {st }}$ century. Upper Saddle River, New Jersey: Pearson Education

Novita, W. (2007). Serba serbi anak: yang perlu diketahui seputar anak dari dalam kandungan hingga masa sekolah. Jakarta: Gramedia. 
Piirto, J. (2009). Gifted and Talented. Texas: Prufrock Press

Priyatna, Andri. (2013). Pahami Gaya Belajar Anak! Jakarta: Elex Media Komputindo

Santrock, J.W. (1999). Lifespan Development. Boston : Mc.Graw Hill

Sarafino (1999). Health psychology. Boston : McGraw - Hill

Tandry, N. (2011). Mengenal Tahap Tumbuh Kembang Anak \& Masalahnya. Jakarta: BPK Gunung Mulia

Walgito, B. (2010). Bimbingan dan konseling: studi dan karier. Yogyakarta: Penerbit ANDI. 